\title{
A FACTOR ANALYSIS OF STUDENTS'ATTITUDES TOWARDS STATISTICS IN HIGHER LEARNING INSTITUTION MALAYSIA
}

\author{
${ }^{1}$ Rosnalini Mansor, ${ }^{2}$ Bahtiar Jamili Zaini, ${ }^{1,3 *}$ Zahayu Md Yusof, ${ }^{4}$ Wendy Wong \\ ${ }^{1,2,3,4}$ School of Quantitative Sciences, Universiti Utara Malaysia, 06010 UUM Sintok, Kedah, Malaysia \\ ${ }^{3}$ Institute of Strategic Industrial Decision Science Modeling (ISIDM), School of Quantitative \\ Sciences, Universiti Utara Malaysia, 06010 UUM Sintok Kedah \\ *email : zahayu@uum.edu.my
}

Received : 18 Oktober 2018; Accepted : 08 November 2018; Published : 23 December 2018

\begin{abstract}
Attitudes toward statistics have received a great attention by academic and researcher in statistics and mathematics education. This paper investigates students' attitudes towards statistics in one of the Malaysia higher education institution and determined the factors that explain the attitude of students toward statistics. Stratified sampling method was used to select 274 respondents from 18 classes Elementary Statistics course. The attitudes toward statistics were measured using the Survey Attitude Towards Statistics (SAT-36) scale. Factor analysis was applied to identify the factors on students' attitude toward statistics. Findings from factor analysis revealed that seven factors that explain the attitude of the students were self-determination, cognitive competence, effort, value of statistics in professional life, difficulty, statistical solving and value of statistics in everyday life. The results suggested that statistics should be demonstrated in more practical way for developing more positive attitude towards statistics. This could further promote the learning process and students' ability to apply the statistical concepts.
\end{abstract}

Keywords Students'Attitude Towards Statistics, Factor Analysis, Undergraduate Students.

\begin{abstract}
Abstrak
Sikap terhadap statistik telah mendapat perhatian yang besar oleh ahli akademik dan penyelidik dalam bidang pendidikan statistik dan matematik. Kertas kerja ini menyiasat tentang sikap pelajar terhadap statistik di salah sebuah institusi pendidikan tinggi Malaysia dan menentukan faktor-faktor yang menjelaskan sikap pelajar terhadap statistik. Kaedah persampelan berstrata digunakan untuk memilih 274 responden dari 18 kelas kursus Pengantar Statistik. Sikap terhadap statistik diukur dengan menggunakan skala Survey Attitude Towards Statistics (SAT-36). Analisis faktor telah digunakan untuk mengenalpasti faktor-faktor sikap pelajar terhadap statistik. Dapatan dari analisis faktor mendedahkan tujuh faktor yang menjelaskan sikap pelajar adalah kesungguhan sendiri, kecekapan


kognitif, usaha, nilai statistik dalam kehidupan profesional, kesukaran, penyelesaian statistik dan nilai statistik dalam kehidupan seharian. Hasil kajian menunjukkan bahawa statistik perlu didemonstrasikan dengan cara yang lebih praktikal untuk meningkatkan sikap positif terhadap statistik. Ini dapat menggalakkan proses pembelajaran dan keupayaan pelajar untuk menggunakan konsep statistik.

Kata kunci Sikap Pelajar Terhadap Statistik, Faktor Analisis, Pelajar Sarjana Muda.

\section{INTRODUCTION}

In recent years, attitudes toward statistics have received a great attention by academic and researcher in statistics education. Statistics courses are very important because most of the undergraduate students majoring in the social sciences or other fields are required to take statistics as a core subject to complete their study. In statistics course, students learn the concepts, theories and learn how to use or implement statistical methods simultaneously. According to Ramirez, Schau and Emmioglu (2012), statistics courses contribute to a statistically literate society and students' overall motivation. However, statistics have a negative reputation among students. Students tend to experience statistics as a threatening and have an anxiety and negative feelings about statistics (Slootmaeckers, Kerremans \& Adriaensen, 2014).

In our case study at Universiti RBZ, most of the undergraduate students are required to take Elementary Statistics course as one of their subject. The syllabus involves fundamental concepts and techniques including descriptive statistics, probability and some distribution. Many students have no prior experience with statistics needs to take this subject. Therefore, it is undoubtedly that students have anxiety and negative feelings about statistics. Students' attitude has a great effect of their persistence in completing their statistics course.

Attitude is important because attitude is a central part of the human personality. Attitude is described as strong feelings and emotional that has been developed from time to time through repeated emotional reaction that can be positive or negative (Gal, Ginsburg \& Schau, 1997). The important of attitude widely recognized. By measuring attitude, information of people on feelings, action and potential actions towards object can be collected. Attitudes have been extensively studied in educational and psychological research (Coetzee \& van der Merwe, 2010; Cashin \& Elmore, 2005). In these studies, the importance of human behaviour has been a core attitude issue.

Aspect of students' attitude towards statistics need to be paid attention because either their positive or negative attitude will influence their process of learning in understanding statistical theories, concepts, methods and developing useful statistical thinking skills in problem solving (García-Santillán, VenegasMartinez, Escalera-Chávez, 2013; Griffith, Adams, Gu, Hart \& Nichols-Whitehead, 2012). Understanding student attitudes toward statistics is important because it will influences and affects students' motivation to enrol in advanced statistical courses Students with negative attitudes often have a perception that statistics is a difficult 
course to learn. This negative attitude of students can affect the learning process and becomes a major problem to effective learning (Ramirez, Schau \& Emmioglu, 2012). It is believed that there are many factors affecting students' attitude toward statistics. Many researches show that attitude toward statistics are related with math experience and math achievement (Schau, 2003). Some demographic factors also affecting students' attitude toward statistics such as gender (Coetzee \& van der Merwe, 2010; Sulieman, 2015; Hilton, Schau \& Olsen, 2004). Cashin and Elmore (2005) found that there were no statistically significant differences between male and female students with respect to achievement and attitude. However, Coetzee and Van Der Merwe (2010) and Oguan, Halili and Dublin (2013) showed that male students have more positive attitude toward statistics. Age also appears to be a factor that influencing the attitude toward statistics. Older students are likely to more positive towards statistics compare to younger students (Coetzee \& van der Merwe, 2010; Baloglu 2003). This research was design to determine the attitudes of the students toward statistics. Specifically, this answers the question: 'what is the level of students' attitude toward statistics?' and 'what is (are) the factor (s) that can be used to explain the students' attitude toward statistics?' Therefore, the objectives of this study are to determine the level of attitude towards statistics among undergraduate students, which are not from sciences quantitative. Next objective is to identify which are the factors that can best explain attitude toward statistics among undergraduate students. Third objective is to examine the relationship between the underlying factors of attitude towards statistics related to their background.

\section{METHODOLOGY}

This study was conducted using a survey design. Therefore, questionnaires were distributed to the respondents of the survey in order to collect the information regarding students' attitudes towards statistics. Demographic profile like gender, age, race, so name a few were collected. This study used an instrument developed by Schau (2003) called Survey of Attitudes towards Statistics (SATS-36) that contains 36 items, which were designed to measure undergraduate students' attitudes toward statistics. The instruments were assessed using a 7- point scale ranging from "1 strongly disagree" to "7 - strongly agree".

In this study, the population was the non-science quantitative undergraduate students of University RBZ who enrolled in Elementary Statistics course during first semester of 2015/2016 academic years. The total population comprised of 976 students. Students were selected from different courses, ethnic and religious background, gender and age group. With the total population of 976 students, minimum number of 274 respondents was an appropriate sample size to represent the population in this study (Bartlett, Kotrlik \& Higgins, 2001). For that reason, the sample size in this study was set to 274 respondents. Stratified sampling method was used to select sample students. Since there were a total of 18 classes for Elementary Statistics course during 2015/2016 academic years with different class size ranged at 41-57 students, therefore 18 classes considered as strata. Finally, students were randomly selected from each of the strata to make a sample size of total 274 . 


\section{RESULTS AND DISCUSSION}

From the 274 valid and useful responses, female student has the highest number among the respondents with about $81 \%$ while $19 \%$ was male student. According to variable age, most of the respondents' age is range from 20 to 21 years old with $52 \%$. Furthermore, most of the students were in semester three with $48.5 \%, 22.6 \%$ was semester one student, $13.1 \%$ was semester five students and $9.9 \%$ was semester two students. This followed with student semester seven, semester four, semester six and semester eight with $2.9 \%, 1.8 \%, 0.7 \%$, and $0.4 \%$ respectively. Most of the respondents were Malaysian citizen which were $91.6 \%$ and $8.4 \%$ was international students. While for their qualification, most of the respondents were qualified with Matriculation about 36.5\% followed by Sijil Tinggi Pelajaran Malaysia (STPM) (34.3\%), and Diploma (18.6\%).

Factor analysis was applied to identify the underlying factor on students' attitude toward statistics. Factor analysis was conducted to reveal the underlying factors behind students' attitude. Thus, the factors that influenced students' attitude towards statistics were identified. Responses were subjected to a factor analysis using the Principal Component Analysis with varimax rotation method to extract the factors underlying students' attitude and to minimize the number of variables that have high loadings on each other. To measure the appropriateness of factor analysis, we measured sampling adequacy using Kaiser-Meyer-Olkin (KMO). The overall value of sampling adequacy KMO was 0.899 suggesting that the correlation was appropriate for factoring. In addition, the result value of Bartlett's test of sphericity ( $p$-value $<0.001$ ), implying that the correlation matrix was not orthogonal, and therefore appropriate for factoring.

Table 1 indicates that there is highly significant of variance expressed in terms of percentage accounted for seven stages of factors that affecting students' attitude towards statistics. Seven factors were extracted using the eigenvalues-greater-thanone rule. When seven factors were extracted, it means that first seven components form the extracted solution and $63.58 \%$ of the variance would be explained.

Table 1 The percent of variance explained

\begin{tabular}{lccc}
\hline \multirow{2}{*}{ Factor } & \multicolumn{3}{c}{ Rotation Sum of Squared Loading } \\
\cline { 2 - 4 } & Total & $\begin{array}{c}\text { Percentage of } \\
\text { Variance }\end{array}$ & $\begin{array}{c}\text { Cumulative } \\
\text { Percentage }\end{array}$ \\
\hline 1 & 6.424 & 17.846 & 17.846 \\
2 & 4.320 & 11.999 & 29.844 \\
3 & 3.413 & 9.480 & 39.325 \\
4 & 2.856 & 7.933 & 47.257 \\
5 & 2.757 & 7.658 & 54.915 \\
6 & 1.667 & 4.631 & 59.546 \\
7 & 1.452 & 4.034 & 63.581 \\
\hline
\end{tabular}


Table 2 Rotated Factor Matrix

\begin{tabular}{|c|c|c|}
\hline & Description & Factor Loading \\
\hline & \multicolumn{2}{|l|}{ Factor 1: Self-determination } \\
\hline 1. & I like statistics & 0.676 \\
\hline 2. & I enjoy taking statistics courses & 0.601 \\
\hline 3. & I can learn statistics & 0.588 \\
\hline 4. & I understand statistics equation & 0.539 \\
\hline 5. & Statistics should be a required part of my study & 0.609 \\
\hline 6. & Statistical skills will make me more employable & 0.533 \\
\hline 7. & Statistics formulas are easy to understand & 0.689 \\
\hline 8. & Statistics is a subject quickly learned by most people & 0.550 \\
\hline 9. & $\begin{array}{l}\text { I am interested in being able to communicate statistical } \\
\text { information to others }\end{array}$ & 0.741 \\
\hline 10. & I am interested in using statistics & 0.818 \\
\hline 11. & I am interested in understanding statistical information & 0.805 \\
\hline \multirow[t]{2}{*}{12.} & I am interested in learning statistics & 0.820 \\
\hline & \multicolumn{2}{|l|}{$\begin{array}{l}\text { Factor 2: Cognitive Complete } \\
\end{array}$} \\
\hline 13. & I stress during statistics class & 0.621 \\
\hline 14 & I am scared by statistics & 0.689 \\
\hline 15 & I have trouble understanding statistics because of how I think & 0.762 \\
\hline 16 & I have no idea of what's going on in this statistics course. & 0.736 \\
\hline 17 & I make a lot of math errors in statistics & 0.735 \\
\hline \multirow[t]{2}{*}{18} & I find it difficult to understand statistical concepts & 0.517 \\
\hline & \multicolumn{2}{|l|}{$\begin{array}{l}\text { Factor 3: Effort } \\
\end{array}$} \\
\hline 19 & I plan to complete all of my statistics assignments & 0.724 \\
\hline 20 & I plan to work hard in my statistics course & 0.817 \\
\hline 21 & I plan to study hard for every statistics test & 0.867 \\
\hline \multirow[t]{2}{*}{22} & I plan to attend every statistics class session & 0.838 \\
\hline & \multicolumn{2}{|l|}{ Factor 4: Value of statistics in professional life } \\
\hline 23 & Statistics is worthless. & 0.592 \\
\hline 24 & Statistics is not useful in my study & 0.742 \\
\hline 25 & Statistical thinking is not applicable in my life outside my job & 0.744 \\
\hline 26 & I will have no application for statistics in my profession & 0.402 \\
\hline \multirow[t]{2}{*}{27} & Statistics is irrelevant in my life & 0.530 \\
\hline & \multicolumn{2}{|l|}{ Factor 5: Difficulty } \\
\hline 28 & Statistics is a complicated subject & 0.474 \\
\hline 29 & Learning statistics requires a great deal of discipline & 0.690 \\
\hline 30 & Statistics involves massive computations & 0.816 \\
\hline
\end{tabular}


A FACTOR ANALYSIS OF STUDENTS' ATTITUDES TOWARDS STATISTICS IN HIGHER LEARNING INSTITUTION MALAYSIA

\begin{tabular}{|c|l|c|}
\hline 31 & Statistics is highly technical & 0.804 \\
\hline 32 & $\begin{array}{l}\text { Most people have to learn a new way of thinking to do } \\
\text { statistics }\end{array}$ & 0.698 \\
\hline & \multicolumn{2}{|c|}{ Factor 6: Statistical solving } \\
\hline 33 & I feel insecure when I have to solve statistics problem & 0.772 \\
\hline 34 & I get frustrated going over statistics tests in class & 0.614 \\
\hline \multicolumn{2}{|c|}{ Factor 7: Value of statistics in everyday life } \\
\hline 35 & I use statistics in my everyday life & 0.762 \\
\hline 36 & Statistics conclusions are rarely presented in everyday life & 0.783 \\
\hline
\end{tabular}

Table 2 shows the rotated factor matrix for the dataset. Using varimax rotation method with Kaiser Normalization, factor analysis identified seven factors. The first factor is self-determination, which comprised of twelve items with factor loadings ranging from 0.466 to 0.841 . This factor concerned with students' attitude is affected by how they feel about statistics, their belief in cognitive abilities to cope with statistics, how much they value statistics and their interest in statistics. The second factor is cognitive competence with six items and the factor loadings ranging from 0.538 to 0.793 . The cognitive competence factor concerned about students' attitude about their intellectual knowledge and skills when applied to statistics. The third factor is effort comprised of four items with factor loadings ranging from 0.722 to 0.860. This factor represents the amount of work the student expands to study about statistics. The fourth factor is value of the statistics in professional life with five items and their factor loadings ranging from 0.508 to 0.756 . The factor explained the students' attitude about the usefulness, relevance and worth of statistics in personal life. The fifth factor is difficulty contained five items with factor loadings ranging from 0.474 to 0.802 . This factor expresses students' attitude about statistics as a difficult subject. The sixth factor is statistical solving with only two items and their factor loadings are 0.681 and 0.847 . This factor concerned with the students' negative feelings concerning solving of statistics. The last factor is the value of statistics in everyday life and contained two items with factor loading 0.658 and 0.783 . This factor illustrates the students' attitude regarding the usefulness of statistics in daily life.

After examined the factors that explained the attitude of students towards statistics. The attitudes of the students towards statistics will then analyzed using mean calibration for negative attitude and was determined as 1.00 until 3.49, neutral attitude as 3.50 until 4.49 and positive attitude was determined as 4.50 until 7.00 (Oguan, Halili \& Dublin, 2013; Mahmud, 2009).

Table 3 provides the attitudes of the students towards statistics by the factors extracted. Based on our findings, the attitude of the students towards statistics was positive with mean of 4.45 and standard deviation of 0.564 . Although mean is almost reaching of cut-off value of 4.50 with positive attitude, but the results do not indicate a strong positive towards statistics. Students also show a positive attitude on different factor that extracted in the factor analysis. Students tend to have more positive attitude on the self-determination with a high degree of positive attitude 
with mean 5.70. While there was a negative attitude on the factor difficulty with mean 3.43. This indicated that the students perceived statistics as a difficult subject.

Table 3 Overall students' attitude towards statistics

\begin{tabular}{lll}
\hline & Mean & Std.Deviation \\
\hline F1 Self-determination & 5.695 & 1.002 \\
F2 Cognitive Complete & 4.763 & 0.980 \\
F3 Effort & 4.591 & 1.122 \\
F4 Value of statistics in professional life & 4.893 & 1.024 \\
F5 Difficulty & 3.435 & 0.894 \\
F6 Statistical solving & 3.840 & 1.217 \\
F7 Value of statistics in everyday life & 3.954 & 0.777 \\
Overall & $\mathbf{4 . 4 5}$ & $\mathbf{0 . 5 6 4}$ \\
\hline
\end{tabular}

Table 4 shows the results of students' attitude towards statistics as consideration with the demographic profile of students with variables gender, age, and their enrolment when entering university. The results indicated that female students have a positive attitude towards statistics with mean 4.60 as compared to male students with mean 4.37. Extremely, the results illustrated that age range of 18-19, 20-21 and 22-23 years old had a positive attitude towards statistics as compared to the age range of 26-27 years old with a negative attitude with mean of 2.89. Besides, students which qualification of Matriculation, STPM or Diploma had a positive attitude toward statistics with mean of $4.80,4.50$ and 4.55 respectively as compared with other qualification with a mean of 4.06 .

Table 4 Attitude of the students toward Statistics by selected variables

\begin{tabular}{|l|l|l|l|}
\hline Variables & $\mathbf{N}$ & Mean & Standard Deviation \\
\hline Gender & & & \\
\hline Male & 52 & 4.3713 & 0.689 \\
\hline Female & 222 & 4.602 & 0.610 \\
\hline $18-19$ & & & \\
\hline $20-21$ & 52 & 4.733 & 0.720 \\
\hline $22-23$ & 144 & 4.560 & 0.561 \\
\hline $24-25$ & 40 & 4.539 & 4.270 \\
\hline $26-27$ & 7 & 4.27 & 0.851 \\
\hline Qualification & 1 & 2.889 & 0.000 \\
\hline STPM & & & \\
\hline Matriculation & & & 0.618 \\
\hline
\end{tabular}


A FACTOR ANALYSIS OF STUDENTS' ATTITUDES TOWARDS STATISTICS IN HIGHER LEARNING INSTITUTION MALAYSIA

\begin{tabular}{|l|l|l|l|}
\hline Diploma & 51 & 4.549 & 0.629 \\
\hline Others & 29 & 4.060 & 0.708 \\
\hline
\end{tabular}

Based on Table 2-4, seven factors were extracted from factor analysis. Those seven factors were (i) self-determination, (ii) cognitive competence, (iii) effort, (iv) value of statistics in professional life, (v) difficulty, (vi) statistical solving and (vii) value of statistics in everyday life. These are the factors that explained the attitude of the students towards statistics. Overall, there was a positive attitude of an undergraduate students towards statistics. Four factors were extracted from the factor analysis, which are self-determination, cognitive competence, effort, and value of statistics in professional life, able to show positive attitudes towards statistics. Female students tend to have more positive attitude towards statistics compared to male students. Extremely, most of the older students have negative attitude towards statistics. Meanwhile, student with Matriculation qualification tends to have more positive attitude towards statistics.

\section{CONCLUSIONS}

Overall, there was a positive attitude of undergraduate students towards statistics. Regarding the gender impact, female students and male students held relatively similar positive attitude towards statistics. However, female students tend to be more positive towards statistics as compared to male students. Female students have more positive perceptions of their intellectual knowledge and skills when applies to statistics and had a more positive attitude about the usefulness, relevance and worth of statistics in professional life compared to male students. Factor analysis extracted seven underlying factors of attitudes of students towards statistics. The seven factors were self-determination, cognitive competence, effort, values of statistics in professional life, difficulty, statistical solving and value of statistics in everyday life are the factor that explained the attitude towards statistics.

Student with Matriculation qualification tends to have more positive attitude towards statistics. Surprisingly, students were getting less positive towards statistics when their age getting older. Besides, students with a good mathematics achievement have a positive relationship with the attitudes towards statistics. Students with a good mathematics achievement tend to be more positive towards statistics. They have more positive attitudes as they have intellectual knowledge and skills when applying statistical concepts and more determination to take statistic courses. Besides, they also tend to have a positive attitude about the usefulness, relevance and worth of statistics in professional life.

Academician can use the results of this study. They need look forward on their teaching and learning approaches in order to improve students' attitudes toward statistics. Improving students' attitudes toward statistics will have direct positive impacts on learning statistics. Furthermore, the findings can disclose educators and students the factors affecting attitudes of students towards statistics. Hence, it is vital 
to understand qualification and knowledge of students to develop an interesting plan to improve their feeling and attitude towards statistics.

\section{REFERENCES}

Bartlett JE, Kotrlik JW, Higgins CC. (2001). Organizational Research: Determining Appropriate Sample Size in Survey Research. Information Technology, Learning and Performance Journal, 19(1), 43-50.

Baloglu M. (2003). Individual differences in statistics anxiety among college students. Personality and Individual Differences, 34(5), 855-865.

Cashin SE, Elmore PB. (2005). The Survey of Attitudes Toward Statistics Scale: A Construct Validity Study. Educational and Psychological Measurement, 65 (3), 509-524.

Ramirez C, Schau C, Emmioglu E. (2012). The importance of attitudes in statistics education. Statistics Education Research Journal, 11(2), 57-71.

Coetzee S, van der Merwe P. (2010). Industrial Psychology Students' Attitudes Towards Statistics. SA Journal of Industrial Psychology, 236(1), 1-8.

Gal I, Ginsburg L, Schau C. (1997). Monitoring attitudes and beliefs in statistics education. Assessment Challenge in Statistics Education, 37-51.

García-Santillán A, Venegas-Martinez F, Escalera-Chávez ME. (2013). An Exploratory Factorial Analysis To Measure (Empirical Study in Undergraduate Students). International Journal of Research and Revise in Applied Sciences, 356-366.

Griffith JD, Adams LT, Gu LL, Hart CL, Nichols-Whitehead P. (2012). Students' Attitudes Toward Statistics Across The Disciplines: A Mixed-Methods Approach. Statistics Education Research Journal, 11(2), 45-56.

Hilton SC, Schau C, Olsen J A. (2004). Survey of Attitudes Toward Statistics: Factor Structure Invariance by Gender and by Administration Time. Structural Equation Model A Multidiscipline Journal, 11(1), 92-109.

Mahmud Z. A. (2009). Discriminant Analysis of Perceived Attitudes Toward Statistics and Profiles Identification of Statistics Learners 2 Related Studies on Attitudes Toward. In: the 2nd WSEAS International Conference on Multivariate Analysis and its Application in Science and Engineering, 41-47.

Oguan Jr FE, Halili LM, Dublin AC. (2013). Exploring Students' Attitudes and Performance toward Statistics Across the Discipline: Does Attitude Affect Performance? International Journal of multidisciplinary Research Academy, 1(9), 33-62.

Schau C. (2003). Students' Attitudes: The “Other" Important Outcome in Statistics Education. In: Joint Statistics Meetings.

Slootmaeckers K, Kerremans B, Adriaensen J.(2014). Too afraid to learn: Attitudes towards statistics as a barrier to learning statistics and to acquiring quantitative skills. Politics, 34(2), 191-200.

Sulieman H. (2015). Students' Conceptions of Statistics: An Exploration of Attitudes across Majors. International Journal of Research Education, 3(2), 158. 